\title{
Determination of Virulence Phenotypes of Plasmopara halstedii in the United States
}

\author{
Michelle A. Gilley, ${ }^{1}$ Thomas J. Gulya, ${ }^{2}$ Gerald J. Seiler, ${ }^{2}$ William Underwood, ${ }^{2}$ Brent S. Hulke, ${ }^{2}$ Christopher G. Misar, ${ }^{2}$ \\ and Samuel G. Markell ${ }^{1, \dagger}$ \\ ${ }^{1}$ Department of Plant Pathology, North Dakota State University, Fargo, ND 58102 \\ ${ }^{2}$ USDA-ARS Sunflower Research Unit, Fargo, ND 58102
}

\begin{abstract}
Downy mildew, caused by Plasmopara halstedii (Farl.) Berl. and de Toni, is an economically important disease in cultivated sunflowers, $\mathrm{Hel}$ ianthus anпииs L. Resistance genes incorporated into commercial hybrids are used as an effective disease management tool, but the duration of effectiveness is limited as virulence evolves in the pathogen population. A comprehensive assessment of pathogen virulence was conducted in 2014 and 2015 in the U.S. Great Plains states of North Dakota and South Dakota, where approximately $75 \%$ of the U.S. sunflower is produced annually. The virulence phenotypes (and races) of 185 isolates were determined using the U.S. standard set of nine differentials. Addi-

was identified on several genes, new virulence was identified on the $P l_{8}$ resistance gene, and no virulence was observed on the $P l_{A r g}, P l_{15}, P l_{17}$ and $P l_{18}$ genes. Results of this study suggest that three additional lines should be used as differentials and agree with previous studies that six lines proposed as differentials should be used in two internationally accepted differential sets. For effective disease management using genetic resistance, it is critical that virulence data be relevant and timely. This is best accomplished when pathogen virulence is determined frequently and by using genetic lines containing resistance genes actively incorporated into commercial cultivars.
\end{abstract} tionally, the virulence phenotypes of 61 to 185 isolates were determined on 13 additional lines that have been used to evaluate pathogen virulence in North America and/or internationally. Although widespread virulence
Keywords: oomycetes, field crops, oilseeds and legumes, pathogen diversity, disease management, cultivar/resistance, race
Sunflower, Helianthus annuus L., is an important crop that is grown for oil, direct human consumption, and bird feed. Although $H$. annuus is native to North America, the production of the crop is greatest in Russia, Ukraine, the European Union, and Argentina (USDA-FAS 2019). In the United States, about 75 to $80 \%$ of the approximately 500,000 to 600,000 ha of sunflower produced annually are grown in the North Central Great Plains states of North Dakota and South Dakota (USDA-NASS 2019). Downy mildew, caused by the biotrophic oomycete pathogen Plasmopara halstedii (Farl.) Berl. and de Toni, is also native to North America but now occurs in all production regions except Australia and New Zealand (CABI 2016; Constantinescu and Thines 2010; Kolte 1985; Leppik 1966). Primary infection occurs when zoosporangia infect young root tissue, causing a systemic infection that usually results in severe stunting and plant death. Prevalence of downy mildew varies globally, but downy mildew is one of the most frequent and economically important diseases of cultivated sunflower in the North Central Great Plains of North America (Gulya et al. 2013, 2019).

Qualitative genetic resistance is one of the most important tools for sunflower downy mildew management (Tourvieille de Labrouhe et al. 2008). Beginning in the 1960s, single dominant resistance genes denoted $\mathrm{Pl}$ (for Plasmopara) were identified and bred into commercially produced sunflower. To date, dozens of resistance genes, originating primarily from wild Helianthus spp., have been identified in both public and private germplasm (Bertero de Romano

${ }^{\dagger}$ Corresponding author: S. G. Markell; samuel.markell@ndsu.edu

*The $\boldsymbol{e}$-Xtra logo stands for "electronic extra" and indicates that one supplementary table is published online.

The author(s) declare no conflict of interest.

Accepted for publication 21 May 2020.

This article is in the public domain and not copyrightable. It may be freely reprinted with customary crediting of the source. The American Phytopathological Society, 2020. et al. 2010; Gascuel et al. 2015; Hulke et al. 2018; Liu et al. 2012, 2019; Ma et al. 2017; Miller and Gulya 1991; Miller et al. 2002; Molinero-Ruiz et al. 2003; Mulpuri et al. 2009; Pecrix et al. 2018; Rahim et al. 2002; Qi et al. 2015, 2016; Vear et al. 2008; Vincourt et al. 2012; Zhang et al. 2017; Zimmer and Kinman 1972). Many of these genes have been deployed singly on a global scale, however, and $P$. halstedii can quickly evolve to confer virulence on solitary genes (Markell et al. 2016; Tourvieille de Labrouhe et al. 2010; Virányi et al. 2015).

As $P$. halstedii began to confer virulence on resistance genes, the selection of genotypes containing differing resistance genes to be used as differentials was warranted. Initially, differentiation of pathogen virulence was undertaken independently in Canada, France, Hungary, Serbia, and the United States (Gulya et al. 1991; Sackston et al. 1990). However, lines utilized as differentials and the "race" nomenclatures used to define the aggregate virulence phenotypes were not uniform (Gulya et al. 1998). For instance, North America used a nomenclature based on the order of race identification, where race 1 and race 2 were the first identified, and races 3, 4, and 5 followed (Carson 1981; Gulya et al. 1997; Sackston et al. 1990), whereas some in Europe used a race nomenclature in which letters were used to denote the different virulence combinations. As the number of races increased, the two different nomenclatures impeded communication and the deployment of effective resistance internationally (Gulya et al. 1998).

In 1998, Gulya et al. (1998) proposed nine standardized, publicly available, fixed inbred lines containing resistance genes that could be used as differential lines: HA 304, RHA 265, RHA 274, PMI3, PM 17, 803-1, HA-R4, QHP1, and HA 335. A race nomenclature was proposed in which differential lines were arranged into triplets (set of three lines), and each differential within the triplet was assigned a numerical value if virulence was expressed (differential $1=1$, differential $2=2$, and differential $3=4$ ). These values were then totaled, and the virulence of the triplet was expressed as a single number ( 0 to 7). The race of $P$. halstedii was expressed as the value of each triplet presented in order (for example, race 734). The proposed differentials and nomenclature were presented internationally (Tourvieille de Labrouhe et al. 2000) and were widely accepted by the international 
community. Since that proposal, substitutions of differential lines with alternate germplasm containing the same genes has occurred, and only the original proposed differential lines D-3 (RHA 274), D-8 (HA-R4), and D-9 (HA 335) have consistently been used globally (Trojanová et al. 2017). In 2012, scientists at Institut National de la Recherche Agronomique (INRA) proposed changes to two of the original nine differential lines: GB would replace HA 304, the susceptible check, for differential D-1 and QHP2 would replace QHP1 for differential D-8 (Tourvieille de Labrouhe et al. 2012). Canada replaced HA 304, the susceptible check, with HA 300 (Rashid 2014). In the United States, Gulya used HA 300 for the susceptible check, DM-2 instead of PMI3, and HA-R5 instead of QHP1 as he proposed in 1995 (Gulya 1995). The current set of differentials includes Mycogen 270 (susceptible), RHA $265\left(\mathrm{Pl}_{1}\right)$, RHA $274\left(\mathrm{Pl}_{2} /\right.$ $\left.\mathrm{Pl}_{21}\right)$, DM-2 (unknown gene), PM17 $\left(\mathrm{Pl}_{5-}\right), 803-1\left(\mathrm{Pl}_{5+}\right)$, HA-R4 $\left(P l_{16}\right)$, HA-R5 $\left(P l_{13}\right)$, and HA $335\left(P l_{6}\right)$ (Pecrix et al. 2018; Vear et al. 2008).

Since the proposal of the nine differential triplet system, additional resistance genes have been identified, and many have been deployed. In 1999, the United States Department of Agriculture (USDA) released RHA 419 and RHA 420, which contained a resistance gene originally identified in $H$. argophyllus and subsequently was named $P l_{A r g}$ (Miller et al. 2002). The naming of this gene was a break from the traditional numbering of resistance genes, and this gene was not the first resistance gene found from $H$. argophyllus (Dußle et al. 2004; Imerovski et al. 2014; Vear et al. 2008). In 2001, RHA 436, RHA 437, and RHA 438 were released with $\mathrm{Pl}_{8}$ from RHA 340 and high-oleic germplasm (Miller et al. 2004). TX-16R was released by USDA in 2005 from wild $H$. annuus, and the resistance gene $P_{33}$ was identified in 2019 (Liu et al. 2019). In 2006, line HA 458 was released with resistance gene $P l_{17}$, originally from wild $H$. annuus. In 2015, line HA-DM1 was released with resistance gene $P l_{18}$ originally from $H$. argophyllus, and a proprietary inbred line from the seed company Nidera in Argentina (now Syngenta, Basel, Switzerland) was released with resistance gene $\mathrm{Pl}_{15}$ (Bertero de Romano et al. 2010; Dußle et al. 2004; Paniego et al. 2012; Qi et al. 2015, 2016; Vear et al. 2008). In 2018, three downy mildew-resistant confection lines, HA-DM2 $\left(\mathrm{Pl}_{\mathrm{Arg}}\right)$, HA-DM3 $\left(\mathrm{Pl}_{17}\right)$, and HA-DM4 $\left(P l_{18}\right.$ ), were registered (Ma et al. 2018). $P l_{19}$ from wild $H$. annuus has been introgressed into confection sunflower and released by USDA in 2017 as HA-DM5, and it is anticipated that $P l_{19}$ will be combined with $\mathrm{Pl}_{A r g}$ and $\mathrm{Pl}_{18}$ into a single line for durable downy mildew control in confection sunflowers (Zhang et al. 2017).

Consequently, the current set of nine differentials (and the genes they contain) are insufficient to accurately assess the virulence phenotype of the $P$. halstedii populations globally. Researchers have already been supplementing the current differential set to better understand the virulence phenotype of the pathogen, but the lines and genes used have not been consistent (Iwebor et al. 2018; Molinero-Ruiz et al. 2002; Trojanová et al. 2017). Similarly, supplemental lines have been used to assess virulence in the United States, including RHA $340\left(\mathrm{Pl}_{8}\right)$, HA $458\left(\mathrm{Pl}_{17}\right)$, HA-DM1 $\left(\mathrm{Pl}_{18}\right)$, TX-16R $\left(\mathrm{Pl}_{33}\right)$, RHA $428\left(\mathrm{Pl}_{34}\right)$, and RHA 419/420/464/468 $\left(\mathrm{Pl}_{\mathrm{Arg}}\right)$ (Gilley and Markell 2019; Gilley et al. 2016; Gulya et al. 2014; Money et al. 2019; Talukder et al. 2019). In 2012, scientists at INRA proposed the addition of six lines that contain genes not represented in the original differential set: Y7Q $\left(\mathrm{Pl}_{6-}\right)$, PSC8 $\left(\mathrm{Pl}_{2}\right)$, XA $\left(\mathrm{Pl}_{4}\right)$, PSS2RM $\left(P l_{6} / P l_{21}\right)$, VAQ $\left(P l_{5}\right)$, and RHA $419\left(P l_{A r g}\right)$ (Tourvieille de Labrouhe et al. 2012). The rapid identification of new resistance genes and the inconsistency of germplasm used as differentials are again impeding effective communication, determination of virulence of pathogen populations, and subsequent deployment of resistance genes.

Surveys of pathogen virulence have occurred in multiple growing regions for decades. In 2015, Virányi et al. (2015) summarized pathogen virulence in North and South America and Europe from 2007 through 2013 in comparison with prior years, and they identified 42 distinct races of $P$. halstedii found internationally. Recently, 50 distinct races were identified in a review of international pathogen virulence (Spring et al. 2018). Virulence to all nine original differential lines has been identified, although a single isolate conferring virulence on all nine of the internationally accepted differential lines has not yet been found (Gascuel et al. 2015; Spring et al. 2018; Virányi et al. 2015). In Argentina, isolates virulent to the $P l_{15}$ resistance gene have been identified (Bazzalo et al. 2016). The $P l_{15}$ resistance gene is not one of the currently accepted or proposed differentials. In the United States, 23 races have been reported (Virányi et al. 2015), and virulence occurred in high numbers to many of the initial genes deployed. Between 2009 and 2013, virulence testing in the United States was performed on additional lines containing specific genes of interest (Gulya et al. 2014). In that work, $38 \%$ of 520 isolates tested overcame the $P l_{6}$ gene (Gulya et al. 2014; Virányi et al. 2015). Similarly, virulence on the $P l_{16}$ and $P l_{13}$ genes was found in $2.8 \%$ of 470 isolates tested in the United States between 1998 and 2009 and was rarely found between 2010 and 2013 (T. Gulya, data not presented). As of 2013, virulence on the $\mathrm{Pl}_{8}$, $\mathrm{Pl}_{\mathrm{Arg}}, \mathrm{Pl}_{15}, \mathrm{Pl}_{17}$, and $\mathrm{Pl}_{33}$ genes had not yet been reported in the United States (Gulya et al. 2014; Virányi et al. 2015). Virulence information determined in the United States on specific lines is critical for determination of pathogen virulence on specific resistance genes, but an effort to fully evaluate pathogen virulence and the utility of different germplasm used as differentials is needed.

The objectives of this study are to (i) determine the virulence phenotypes of the $P$. halstedii population in the U.S. North Central Great Plains using the standard set of nine differential lines, the six lines proposed as differentials by INRA (Tourvieille de Labrouhe et al. 2012), and additional lines previously utilized as supplemental differentials in the United States, and (ii) evaluate the usefulness of all the additional lines as possible additions into the differential set in the future.

\section{Materials and Methods}

Pathogen materials. Pathogen isolates used in this study were collected during a disease survey in 2014 and 2015 (Gilley et al. 2016) and by soliciting sample submission from personnel in USDA-Agricultural Research Service (USDA-ARS), Extension, and seed companies. The survey route was concentrated in Central North Dakota and North Central South Dakota, the regions with the highest production of sunflower in the United States (USDANASS 2019), and ranged approximately $500 \mathrm{~km}$ north to south and $200 \mathrm{~km}$ east to west. Individual fields were arbitrarily selected and were typically at least 3 to $8 \mathrm{~km}$ apart. Collections were made by destructively collecting sunflower plants with signs and symptoms of infection. When possible, a minimum of three downy mildewinfected plants, selected at least $30 \mathrm{~m}$ apart, were collected. One whole plant with the roots removed or several leaves from one plant was considered an isolate.

In 2014, 187 isolates were collected from 68 fields in the survey, and an additional 37 isolates were collected and submitted by personnel from the USDA-ARS, state Extension services, and seed companies. In 2015, 159 isolates were collected from 59 fields in North Dakota and South Dakota, and an additional 88 isolates were collected and submitted from North Dakota, South Dakota, Minnesota, and Nebraska by personnel from USDA-ARS, state Extension services, and seed companies. Thus, for the 2 years surveyed, a total of 471 isolates were collected.

All samples were increased in the greenhouse on two susceptible sunflower hybrids with no known resistance genes, Mycogen 270 and Mycogen 8N358CL (Corteva Agriscience, Wilmington, DE). Seeds were sterilized before germination by soaking in $8.25 \%$ sodium hypochlorite (Clorox, Oakland, CA), deionized water, and dish detergent for $15 \mathrm{~min}$ before rinsing thoroughly. Seeds were spread in a single layer on moistened machine cloth on a tray and placed in a room-temperature germination chamber until radicles were at least $1 \mathrm{~cm}$ long. As soon as possible after the seedling radicles were $1 \mathrm{~cm}$ long, they were used or they were placed in crisper boxes with moistened blue blotter paper and refrigerated.

To increase $P$. halstedii from the initial field samples, a zoosporangia suspension was prepared from symptomatic leaves within 1 week of their collection using methods described by Gulya 
(1996). To induce sporulation on a field sample without sporulation, leaves were placed in the mist chamber on 100-mm Petri dishes on top of dampened machine cloth in trays for 24 to $48 \mathrm{~h}$ before inoculating susceptible seedlings. Symptomatic leaves were placed in a sample bottle containing approximately $80 \mathrm{ml}$ of a $10 \mathrm{mM}$ calcium chloride solution and shaken (Gulya 1996). This spore suspension and 20 to 35 pregerminated seedlings were mixed in 2-oz disposable plastic cups and placed in a dry, dark chamber for 3 to $6 \mathrm{~h}$ at 16 to $18^{\circ} \mathrm{C}$. Once inoculation was completed, infected seedlings were placed on a sand/perlite (3:2 in 2014 and 3:1 in 2015) substrate in 26-cm square plastic flats (T. O. Plastics, Clearwater, MN). Seedlings were covered with a thin layer of pure sand, and flats were placed in a greenhouse with a 16 -h photoperiod at 20 to $30^{\circ} \mathrm{C}$. Seed coats were removed a few days after emergence to enable better sporulation. Seedlings were grown in a greenhouse until plants were beginning to develop true leaves, which took from 8 to 11 days, depending on greenhouse temperatures.

To induce sporulation for reisolation of the pathogen, plants were placed in a dark mist chamber at a temperature of 16 to $18^{\circ} \mathrm{C}$ for 16 to $48 \mathrm{~h}$. After sporulation, each isolate in its square flat was separated from other isolates for several hours until dry. The cotyledons covered with zoosporangia were clipped with sterilized scissors, desiccated, and stored in $1.8-\mathrm{ml}$ cryotubes at $-80^{\circ} \mathrm{C}$. Cotyledons were desiccated with 8-mesh Drierite desiccant (calcium sulfate) for 3 to 5 days in 2014 and 5 to 10 days in 2015 at room temperature. Sporulated seedlings for immediate inoculations were stored in plastic bags in the refrigerator for up to 1 week.

Genetic materials. Virulence phenotypes were determined on three groups of genetic materials. For the purposes of this study, these three groups are hereafter referred to as the U.S. standard differentials, the proposed INRA differentials, and the U.S. supplemental lines (Table 1). The U.S. standard differentials consist of Mycogen 270, RHA 265, RHA 274, DM-2, PM 17, 803-1, HAR4, HA-R5, and HA 335. The proposed INRA differentials include lines Y7Q, PSC8, XA, PSS2RM, VAQ, and RHA 419. The U.S. supplemental lines include RNID, RHA 340, HA 458, HA-DM1, RHA 468, TX-16R, and RHA 428.

Determination of virulence phenotypes. Fresh pathogen zoosporangia were used to determine all virulence phenotypes. To produce fresh inoculum, $1.8-\mathrm{ml}$ cryotubes containing sporulated, desiccated cotyledons were removed from storage in a $-80^{\circ} \mathrm{C}$ freezer. The selected cryotubes were heat shocked in warm water around $38^{\circ} \mathrm{C}$ for 1 to $2 \mathrm{~min}$. Infected cotyledons were placed in labeled 2 oz disposable plastic cups with about 30 pregerminated seedlings of the susceptible hybrid, Mycogen 270, in $35 \mathrm{ml}$ of a $10 \mathrm{mM}$ calcium chloride solution for at least $5 \mathrm{~h}$. Inoculated seedlings were placed on the sand/perlite blend in the $26-\mathrm{cm}$ flats and covered with a light layer of sand. After 10 to 11 days in the greenhouse, the plants were transferred to the mist chamber for sporulation. Then, eight to 12 seedlings were selected as inoculum for virulence phenotyping and used immediately or left to dry before being stored in plastic bags in the refrigerator for use within 1 week.

Seeds of each differential line were surface sterilized and germinated on dampened machine cloth on metal trays in the germination chamber at room temperature as described previously. When sufficient seed was available, 20 seeds per line were used for virulence screening. Two to three sporulated cotyledons per pathogen isolate were added per $100 \mathrm{ml}$ of solution, with approximately $25 \mathrm{ml}$ of spore solution required to cover the seedlings in each 2-oz disposable plastic cup for each line on the isolate tray. Zoosporangia

Table 1. Sunflower differential lines and supplemental lines used to determine virulence phenotype of Plasmopara halstedii isolates in this study ${ }^{\mathrm{a}}$

\begin{tabular}{|c|c|c|c|c|c|}
\hline \multicolumn{2}{|c|}{ Triplet code } & & \multirow[b]{2}{*}{ Lines } & \multirow[b]{2}{*}{ Resistance gene $^{\mathbf{b}}$} & \multirow[b]{2}{*}{ Origin $^{c}$} \\
\hline Digit & $\overline{\text { Value }}$ & & & & \\
\hline \multicolumn{6}{|c|}{ U.S. standard differentials ${ }^{d}$} \\
\hline \multirow[t]{3}{*}{ First } & 1 & D-1 & Mycogen 270 & None & \\
\hline & 2 & D-2 & RHA 265 & $\mathrm{Pl}_{1}$ & USDA \\
\hline & 4 & D-3 & RHA 274 & $\mathrm{Pl}_{2} / \mathrm{Pl}_{21}$ & USDA \\
\hline \multirow[t]{3}{*}{ Second } & 1 & D-4 & DM-2 & Unknown & USDA \\
\hline & 2 & D-5 & PM 17 & $\mathrm{Pl}_{5-}$ & USDA \\
\hline & 4 & D-6 & $803-1$ & $\mathrm{Pl}_{5+}$ & IFVC \\
\hline \multirow[t]{4}{*}{ Third } & 1 & D-7 & HA-R4 & $\mathrm{Pl}_{16}$ & USDA \\
\hline & 2 & D-8 & HA-R5 & $\mathrm{Pl}_{13}$ & USDA \\
\hline & 4 & D-9 & HA 335 & $\mathrm{Pl}_{6}$ & USDA \\
\hline & & & Proposed INRA dif & & \\
\hline \multirow[t]{3}{*}{ Fourth } & 1 & D-10 & Y7Q & $P l_{\sigma^{-}}$ & INRA \\
\hline & 2 & D-11 & PSC8 & $\mathrm{Pl}_{2}$ & INRA \\
\hline & 4 & D-12 & XA & $\mathrm{Pl}_{4}$ & INRA \\
\hline \multirow[t]{11}{*}{ Fifth } & 1 & D-13 & PSS2RM & $P l_{6} / P l_{21}$ & INRA \\
\hline & 2 & D-14 & VAQ & $\mathrm{Pl}_{5}$ & INRA \\
\hline & 4 & D-15 & RHA 419 & $P l_{A r g}$ & USDA \\
\hline & & & U.S. supplement & & \\
\hline & & & RNID & $P l_{15}$ & Nidera, S.A. (Argentina) \\
\hline & & & RHA 340 & $\mathrm{Pl}_{8}$ & USDA \\
\hline & & & HA 458 & $P l_{17}$ & USDA \\
\hline & & & HA-DM1 & $P l_{18}$ & USDA \\
\hline & & & RHA 468 & $P l_{A r g}$ & USDA \\
\hline & & & TX-16R & $\mathrm{Pl}_{33}$ & USDA \\
\hline & & & RHA 428 & $\mathrm{Pl}_{34}$ & USDA \\
\hline \multicolumn{6}{|c|}{$\begin{array}{l}\text { a D-1 to D-15 = lines of differential set. } P l \text { indicates Plasmopara resistance gene where known. } \\
\text { bertero de Romano et al. (2010); Gascuel et al. (2015); Hulke et al. (2018); Liu et al. (2012, 2019); Ma et al. (2017); Miller and Gulya (1991); Miller et al. (2002); } \\
\text { Molinero-Ruiz et al. (2003); Money et al. (2019); Mulpuri et al. (2009); Pecrix et al. (2018); Qi et al. (2015, 2016); Rahim et al. (2002); Talukder et al. (2019); } \\
\text { Vincourt et al. (2012); Zhang et al. (2017); Zimmer and Kinman 1972. } \\
\text { c USDA = United States Department of Agriculture; IFVC = Institute for Field and Vegetable Crops, Yugoslavia; and INRA = Institut National de la Recherche } \\
\text { Agronomique, France. } \\
\text { d Gulya (1995). } \\
\text { e Tourvieille de Labrouhe et al. (2012). } \\
\text { fing } \\
\text { Supplemental sunflower lines used to distinguish additional virulence not represented by resistance genes in the U.S. standard and proposed INRA differential } \\
\text { lines. }\end{array}$} \\
\hline
\end{tabular}


concentrations in inoculum solution were initially calibrated by visual assessment of sporulation on selected cotyledons. Concentrations were enumerated microscopically on representative solutions to ensure that zoosporangia exceeded $20,000 / \mathrm{ml}$, with a target rate of $40,000 / \mathrm{ml}$ to $60,000 / \mathrm{ml}$ (Trojanová et al. 2017). Trays were placed in the dark in the mist chambers for a minimum of $3 \mathrm{~h}$. Two $38 \times 53 \times$ $7.6 \mathrm{~cm}$ flats (Kadon, Dayton, $\mathrm{OH}$ ) were filled about $3 / 4$ full with a sand/perlite (3:2 in 2014 and 3:1 in 2015) substrate for each isolate. The sand/perlite blend was leveled, lightly watered, and then pressed to create shallow trenches for each differential or supplemental line. Inoculated seeds were placed root down in the trenches with sterile forceps, covered with sand, and gently watered. Seed coats were removed prior to sporulation, so that cotyledons and true leaves were visible. True leaves were visible on each line after 11 to 14 days. Flats were misted and held for 16 to $48 \mathrm{~h}$ at $100 \%$ relative humidity at 16 to $18^{\circ} \mathrm{C}$. Plants were air dried completely before rating susceptibility and resistance.

Assessment of virulence on each line was done using a scale proposed by INRA, where SI = susceptible, sporulation on cotyledons and true leaves; SII = abundant sporulation on cotyledons only; RII = weak sporulation on cotyledons; and RI = resistant, no sporulation (Tourvieille de Labrouhe et al. 2012).

Race determination. In order to express the aggregate virulence phenotype of isolates as races, the internationally accepted triplet code nomenclature was used (Tourvieille de Labrouhe et al. 2000). In the triplet code system, each set of three differential lines is given a numerical value (Table 1). The first three lines correspond to the first digit, the second three lines correspond to the second digit, and the third three lines correspond to the third digit. Each digit ranges from 0 if all three lines were resistant to 7 if all three lines were susceptible. If a line is resistant, it is given a value of 0 . Otherwise, the first line is given a 1 , the second line a 2 , and the third line a 4 . The values for all three lines in the set are then added. For example, the 7 in the 714 is because $1+2+4=7$. The 1 for the second digit is because the first line was susceptible, and the remaining two lines were resistant and therefore 0 . For the third digit, the first two lines were 0 and the last line was a 4 .

Additional proposed differentials are added in triplets. The two triplets in the proposed INRA differentials were added to the original race classification as triplets 4 and 5 (Tourvieille de Labrouhe et al. 2012). The addition of three differentials of the U.S. supplemental lines were proposed as a sixth triplet, bringing the total race name to six digits.

\section{Results}

Pathogen materials. A total of 185 P. halstedii isolates were generated from 471 infected plant samples collected during the disease survey or received from cooperators. Except for one field, only one isolate was selected per field or plot. In 2014, 105 isolates were virulence phenotyped from 62 locations in North Dakota, 13 locations in South Dakota, and six locations in Minnesota. In 2015, 80 isolates were virulence phenotyped from 59 locations in North Dakota, 12 locations in South Dakota, five locations in Minnesota, and four locations in Nebraska. The virulence phenotypes of all 185 P. halstedii isolates were determined on the U.S. standard differentials (Table 2, Supplementary Table S1).

The number of $P$. halstedii isolates tested on proposed INRA differentials and U.S. supplemental lines varied depending on seed quality and quantity (Table 2, Supplementary Table S1). The virulence phenotype of between 61 and $185 P$. halstedii isolates was determined on the proposed INRA differentials and between 67 and 185 isolates on the U.S. supplemental lines. When seed was limited, selection of isolates was prioritized by diversity of locations.

Virulence phenotypes on U.S. standard differentials. Virulence was observed on all nine differential lines from the standard set (Table 2), but no one isolate conferred virulence on all nine lines. The $P l_{l}$ gene in RHA 265, differential D-2, was susceptible to all 185 isolates. The $\mathrm{Pl}_{2} / \mathrm{Pl}_{21}$ gene cluster in RHA 274, differential

Table 2. Number of Plasmopara halstedii isolates collected in 2014 and 2015 in the U.S. North Central Great Plains virulent on the standard set of differential lines

\begin{tabular}{|c|c|c|c|c|c|}
\hline \multirow[b]{2}{*}{ Differential } & \multirow[b]{2}{*}{ Name } & \multicolumn{3}{|c|}{ Isolates virulent/isolates screened } & \multirow{2}{*}{$\begin{array}{l}\text { Percent of isolates } \\
\text { virulent on differential line }\end{array}$} \\
\hline & & 2014 & 2015 & Total & \\
\hline \multicolumn{6}{|c|}{ U.S. standard differentials ${ }^{\mathrm{a}}$} \\
\hline D-1 & Susceptible & $105 / 105$ & $80 / 80$ & $185 / 185$ & $100 \%$ \\
\hline D-2 & RHA 265 & $105 / 105$ & $80 / 80$ & $185 / 185$ & $100 \%$ \\
\hline D-3 & RHA 274 & $101 / 105$ & $70 / 80$ & $171 / 185$ & $92 \%$ \\
\hline D-4 & DM-2 & $83 / 105$ & $57 / 80$ & $140 / 185$ & $76 \%$ \\
\hline D-5 & PM 17 & $10 / 105$ & $4 / 80$ & $14 / 185$ & $8 \%$ \\
\hline D-6 & 803-1 & $9 / 105$ & $3 / 80$ & $12 / 185$ & $6 \%$ \\
\hline D-7 & HA-R4 & $1 / 105$ & $1 / 80$ & $2 / 185$ & $1 \%$ \\
\hline D-8 & HA-R5 & $1 / 105$ & $1 / 80$ & $2 / 185$ & $1 \%$ \\
\hline D-9 & HA 335 & $53 / 105$ & $34 / 80$ & $87 / 185$ & $47 \%$ \\
\hline \multicolumn{6}{|c|}{ Proposed INRA differentials ${ }^{b}$} \\
\hline D-10 & Y7Q & $27 / 65$ & $17 / 26$ & $44 / 91$ & $48 \%$ \\
\hline D-11 & PSC8 & $66 / 66$ & $26 / 26$ & $92 / 92$ & $100 \%$ \\
\hline $\mathrm{D}-12$ & XA & $62 / 66$ & $17 / 26$ & $79 / 92$ & $86 \%$ \\
\hline D-13 & PSS2RM & $18 / 50$ & $7 / 26$ & $25 / 76$ & $33 \%$ \\
\hline D-14 & VAQ & $1 / 35$ & $3 / 26$ & $4 / 61$ & $7 \%$ \\
\hline D-15 & RHA 419 & $0 / 105$ & $0 / 80$ & $0 / 185$ & $0 \%$ \\
\hline \multicolumn{6}{|c|}{ U.S. supplemental lines ${ }^{c}$} \\
\hline & RNID & $0 / 67$ & $0 / 80$ & $0 / 146$ & $0 \%$ \\
\hline & RHA 340 & $2 / 105$ & $5 / 80$ & $7 / 185$ & $4 \%$ \\
\hline & HA 458 & $0 / 65$ & $0 / 79$ & $0 / 144$ & $0 \%$ \\
\hline & HA-DM1 & $0 / 87$ & $0 / 80$ & $0 / 167$ & $0 \%$ \\
\hline & RHA 468 & $0 / 67$ & $0 / 80$ & $0 / 147$ & $0 \%$ \\
\hline & TX-16R & $0 / 85$ & $0 / 80$ & $0 / 165$ & $0 \%$ \\
\hline & RHA 428 & $16 / 67$ & $0 / 0$ & $16 / 67$ & $24 \%$ \\
\hline
\end{tabular}

\footnotetext{
a Gulya (1995).

b Tourvieille de Labrouhe et al. (2012).

c Supplemental sunflower lines used to distinguish additional virulence not represented by resistance genes in the U.S. standard and proposed INRA differential lines.
} 
D-3, and the unknown gene in DM-2, differential D-4, were susceptible to the majority of the collected isolates at 92 and $76 \%$, respectively. All 14 isolates that were avirulent to the $P l_{2} / \mathrm{Pl}_{21}$ gene cluster in RHA 274 were virulent on the $P l_{6}$ gene in HA 335. Virulence on lines PM 17 and 803-1, differential lines D-5 and D-6, with the $P l_{5-}$ and $P l_{5+}$ genes, was limited to 8 and $6 \%$ of the isolates, respectively. Only one isolate each year was virulent on lines HA-R4 and HA-R5, differential lines D-7 and D-8, with resistance genes $P l_{16}$ and $P l_{13}$. Virulence on the $\mathrm{Pl}_{6}$ gene, differential D-9, was found for $50.5 \%$ of the isolates from 2014 and $42.5 \%$ of the isolates from 2015 with an average of $47 \%$.

Virulence phenotypes on proposed INRA differentials. Virulence was observed on all five of the INRA lines (differential lines D-10 to D-14) (Table 2). The $P l_{2}$ resistance gene, differential D11 , and the $\mathrm{Pl}_{4}$ resistance gene, differential D-12, were susceptible to all or most of the isolates screened at 100 and $86 \%$, respectively. The percent of isolates virulent on the $P l_{6 \text { - }}$ resistance gene, differential D-10, and the $P l_{6} / P l_{21}$ resistance gene combination, differential D-13, were 48 and $33 \%$, respectively. The resistance gene $P l_{5}$, differential D-14, was the least susceptible to the screened isolates at $7 \%$ of the isolates virulent. No virulence was observed on USDA line RHA 419, differential D-15, with the $P l_{A r g}$ resistance gene.

Virulence phenotypes on U.S. supplemental lines. No $P$. halstedii isolate conferred virulence on differential lines containing resistance genes $\mathrm{Pl}_{15}$ (RNID), $\mathrm{Pl}_{17}$ (HA 458), $P l_{18}$ (HA-DM1), and $P l_{\text {Arg }}$ (RHA 468) (Table 2). While confirming the pedigree for RHA 468, it was recently hypothesized and confirmed by mapping that its resistance to downy mildew came from $\mathrm{Pl}_{\text {Arg }}$ in RHA 419; accordingly, like RHA 419, no virulence was found on RHA 468 (Hulke et al. 2018). Although no virulence was identified on TX16R, up to six seedlings (out of approximately 20 seedlings) expressed a virulent reaction during testing, indicating possible seed contamination or nongenetic purity of the line. Seven isolates were found over the 2 years in North Dakota that were virulent on RHA 340, which contains the $\mathrm{Pl}_{8}$ gene (Table 2). Because RHA 428 was susceptible to 16 of the 67 isolates it was evaluated in 2014 but not tested in 2015.

Race nomenclature. Based on the U.S. standard differentials only, 12 races were found in 2014 and 2015 among isolates from North Dakota, South Dakota, Minnesota, and Nebraska (Fig. 1). In both years, the most common $P$. halstedii races were 714,710 , and 700 , comprising $77 \%$ of the total races identified. Race 774 was the fourth most frequent race in 2014, whereas race 314 was the fourth most frequent race in 2015. Three races, 304, 707, and 717, were new to the United States; however, they have previously only been identified in France (Spring 2019; Virányi et al. 2015).

Races of $P$. halstedii isolates were also named using the U.S. standard differential set of nine differential lines according to Tourvieille de Labrouhe et al. (2000), the six proposed INRA differentials (Tourvieille de Labrouhe et al. 2012), and the three most important lines from the U.S. supplemental lines into a single new expanded set (Table 3). Using the new proposed six-digit differential set, a total of 16 races were identified, and distinctions among several isolates previously named using the U.S. standard differentials (for example, race 710) were observed (Table 4). This is particularly true for isolates characterized as races 700, 710, and 714, which are now distinguished into two (700600 and 700602), three (710600, 710602, and 710702), and two (714700 and 714710) races, respectively (Table 4).

\section{Discussion}

The results of this study demonstrate that isolates of $P$. halstedii in the North Central United States confer limited to no virulence on multiple genes $\left(\mathrm{Pl}_{\mathrm{Arg}}, \mathrm{Pl}_{13}, \mathrm{Pl}_{15}, \mathrm{Pl}_{16}\right.$, and $\left.P l_{17}\right)$, which are likely to be effective for disease management in the production area. The results of this study also demonstrate that determination of pathogen virulence using the current set of nine lines in the international standard differential set alone is inadequate, and that lines containing additional genes are critical for relevant virulence information. Lines in both the proposed INRA differentials and the U.S. supplemental lines provided critical data on pathogen virulence. We agree with the findings of Tourvieille de Labrouhe et al. (2012) that the addition of the six differentials be added to the nine in the original differential set (Tourvieille de Labrouhe et al. 2000) and further propose that three lines from the U.S. supplemental lines be added as well. The addition of these lines is likely to provide useful information on virulence in the $P$. halstedii population in the future. Additionally, we recognize additional logistical challenges with the frequent addition of lines to the differential set and recommend consideration of a replacement or restructured mechanism to report pathogen virulence in the future.

In this study, the determination of pathogen virulence of a large and diverse collection of $P$. halstedii isolates provided relevant data on the pathogen and simultaneously allowed evaluation of the potential usefulness of 22 current and proposed differential lines used in this study. Results indicate that some lines of the U.S. standard differentials still provide useful information. Differential D-9 is of particular importance, because the $P l_{6}$ gene was widely deployed in commercial hybrids in the United States in the 2000s and continues to be deployed in gene pyramids. Virulence to $P l_{6}$ was first identified in 2009 and thought to be rare (Gulya et al. 2011). In this study, which was conducted 5 and 6 years later, approximately half of the tested isolates conferred virulence to $P l_{6}$. Limited virulence (1 to $8 \%$ ) was observed on four differential lines, D-5 (PM 17), D-6 (803-1), D-7 (HA-R4), and D-8 (HA-R5), in the U.S. standard differentials, suggesting that the genes in these lines may still provide some effective management of downy mildew in the United States. Although these lines were released more than 35 years ago, the genes were only more recently identified and/or mapped for marker assisted selection; therefore, they are not thought to be incorporated into commercial hybrids, which may help explain their perceived longevity (Gascuel et al. 2015; Liu et al. 2012; Mulpuri et al. 2009; Pecrix et al. 2019). Additional lines in the U.S. standard differentials are of less value. All of the 185 isolates evaluated in this study conferred virulence on differentials D-2 (RHA 265) and D-3 (RHA 274), and nearly all conferred virulence on differential D-4 (DM-2). Virulence on these differentials is not surprising, because each contains resistance genes released many decades ago. However, these data are of limited usefulness because it is thought that those resistance genes are no longer actively bred into hybrids. In this study, we used a commercially produced hybrid as a susceptible differential (D-1). However, it is logistically easier to procure seed of a publicly available inbred line, and in future studies we intend to use HA821 (Roath et al. 1986) as (D-1).

Virulence data generated on the proposed INRA differentials was moderately useful regarding the $P$. halstedii population in the United States, because the six lines only added one new resistance gene, $P l_{A r g}$ (RHA 419), that was being deployed in the United States (Tourvieille de Labrouhe et al. 2000, 2012). Virulence was observed on all five of the INRA-released lines D-10 to D-14 (Y7Q, PSC8, XA, PSS2RM, and VAQ), whereas no virulence was identified on

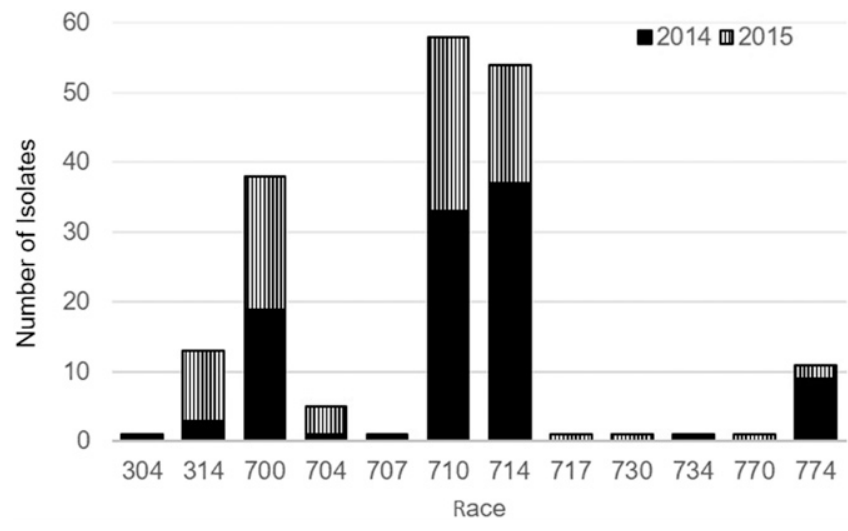

Fig. 1. Plasmopara halstedii races identified from isolates collected in 2014 and 2015 in the U.S. North Central Great Plains using triplet code race nomenclature based on virulence pattern of the U.S. standard differentials (Gulya 1995). 
differential D-15 (RHA 419). However, evaluation of isolates collected in this study on the proposed INRA differentials has the added value of maintaining consistency internationally. Using the race nomenclature proposed in 2012 (Tourvieille de Labrouhe et al. 2012), in which five sets of three differentials are used, distinctions among isolates can be made. One isolate evaluated in this study conferred virulence on D-10 (Y7Q), which has the $P l_{6}$ gene, giving it an aggregate virulence phenotype of 71070 and allowing distinction between 71070 and 71060. In the North Central Great Plains, differential D-11 was not found necessary because all of the isolates tested were virulent on it. However, in France, differential D-11 distinguishes between aggregate virulence phenotypes 30410 and 30430 . Differential D-12, XA, contains a unique gene, $\mathrm{Pl}_{4}$, but most of the isolates tested in the United States conferred virulence on it. Differential D-13 (PSS2RM) contains a novel gene combination of $\mathrm{Pl}_{6} l$ $P l_{21}$, and slightly fewer virulent isolates were found in this study than on differential D-9, which contains just the $P l_{6}$ gene. One isolate in this study conferred virulence on D-13, giving it an aggregate virulence phenotype of 71471, allowing distinction between 71470 and 71471. Differentials D-14 (VAQ), D-5 (PM 17), and D-6 (803-1) contain the $P l_{5}, P l_{5-}$, and $P l_{5+}$ genes, respectively, with similar virulence reactions of isolates tested in this study of between 6 and $8 \%$. Importantly, differential D-4 (DM-2) was originally included in the U.S. standard differentials with the hypothesis that resistance was conferred by $\mathrm{Pl}_{5}$. However, over $75 \%$ of isolates tested in both years of this study were virulent on DM-2, in agreement with Vear et al. (2008) that the line likely contains a different gene than $P l_{5}$. Internationally, the line PMI3, a further selection of DM-2, has been used as a replacement (Tourvieille de Labrouhe et al. 2000). Pecrix et al. (2018) recently reported the gene in PMI3 as $P l_{22}$ (formerly $P l_{P M I 3}$ ), and although it is possible that DM-2 also contains $P l_{22}$, that has not been confirmed. Consequently, it may be prudent to replace DM-2 with PMI3 in the U.S. standard differentials.

Virulence data generated using seven U.S. supplemental lines was valuable. This is particularly true of proposed differential D-17 (RHA 340), because virulence to the $\mathrm{Pl}_{8}$ resistance gene was found in seven isolates of 185 isolates evaluated in the study. This was the first identification of virulence to the gene (Trojanová et al. 2017), which is known to have been bred into commercial hybrids. Virulence was confirmed by phenotyping each isolate on four additional inbred lines with the $P l_{8}$ resistance, RHA 436, RHA 437, RHA 438, and HA 460, all of which were susceptible (data not presented). Of similar importance, no virulence was found on U.S. supplemental lines RNID, HA 458, and HA-DM1, containing resistance genes $P l_{15}, P l_{17}$, and $P l_{18}$, respectively. It is believed that seed companies are actively incorporating at least one, but possibly three, of these newer sources of resistance, making virulence data generated from them in the future useful.

However, three of the lines in the U.S. supplemental lines were determined not to be useful. During this study, mapping and pedigree analysis of RHA 468 determined that its resistance to downy mildew originated from $P l_{A r g}$ in RHA 419 (Hulke et al. 2018), a duplication of the gene in D-15. U.S. supplemental line TX-16R $\left(P l_{33}\right)$ was eliminated from this study because it was suspected as having contaminated seed or an unfixed gene; a majority of the 20 seedlings tested expressing resistance, but a consistent minority (one to six seedlings) expressing susceptibility. The resistance gene in TX$16 \mathrm{R}, \mathrm{Pl}_{33}$, was identified and mapped by Liu et al. (2019) after the completion of this study, and germplasm containing this gene could be useful as a differential line in the future. Another line that could be useful as a differential is RHA 428, which was susceptible to 16 of the 67 isolates evaluated in 2014. However, it is known to have a resistance profile that complements other defeated and widely deployed resistance genes, such as $\mathrm{Pl}_{6}$, and so may be useful for gene pyramiding purposes.

Based on the above results, we propose to add three additional lines containing resistance genes $P l_{15}, \mathrm{Pl}_{8}$, and $\mathrm{Pl}_{17}$ as differentials to the original proposed (with modifications) set of nine differentials (Tourvieille de Labrouhe et al. 2000) and support the additional six differentials proposed by INRA (Tourvieille de Labrouhe et al. 2012). In our study, we used lines RNID (as D-16), RHA 340 (as D-17), and HA 458 (as D-18), but improvements in germplasm with these genes have been made since the study. We propose that RHA 491 (which contains $P l_{15}$ ) and HA 490 (which contains $P l_{17}$ ) be used as D-16 and D-18, respectively (Hulke et al. unpublished). These three genes are thought to provide the most useful information about the $P$. halstedii population to the sunflower community, because they represent a combination of novel resistance genes that are likely to be deployed in commercial hybrids and/or help differentiate the pathogen population globally with confirmed isolates virulent on the $\mathrm{Pl}_{8}$

Table 3. Proposed race nomenclature of Plasmopara halstedii virulence phenotypes identified in this study that incorporates the nine U.S. standard differential lines (Gulya 1995), the differential lines proposed by Tourvieille de Labrouhe et al. (2012), and the three lines proposed in this study ${ }^{\mathrm{a}}$

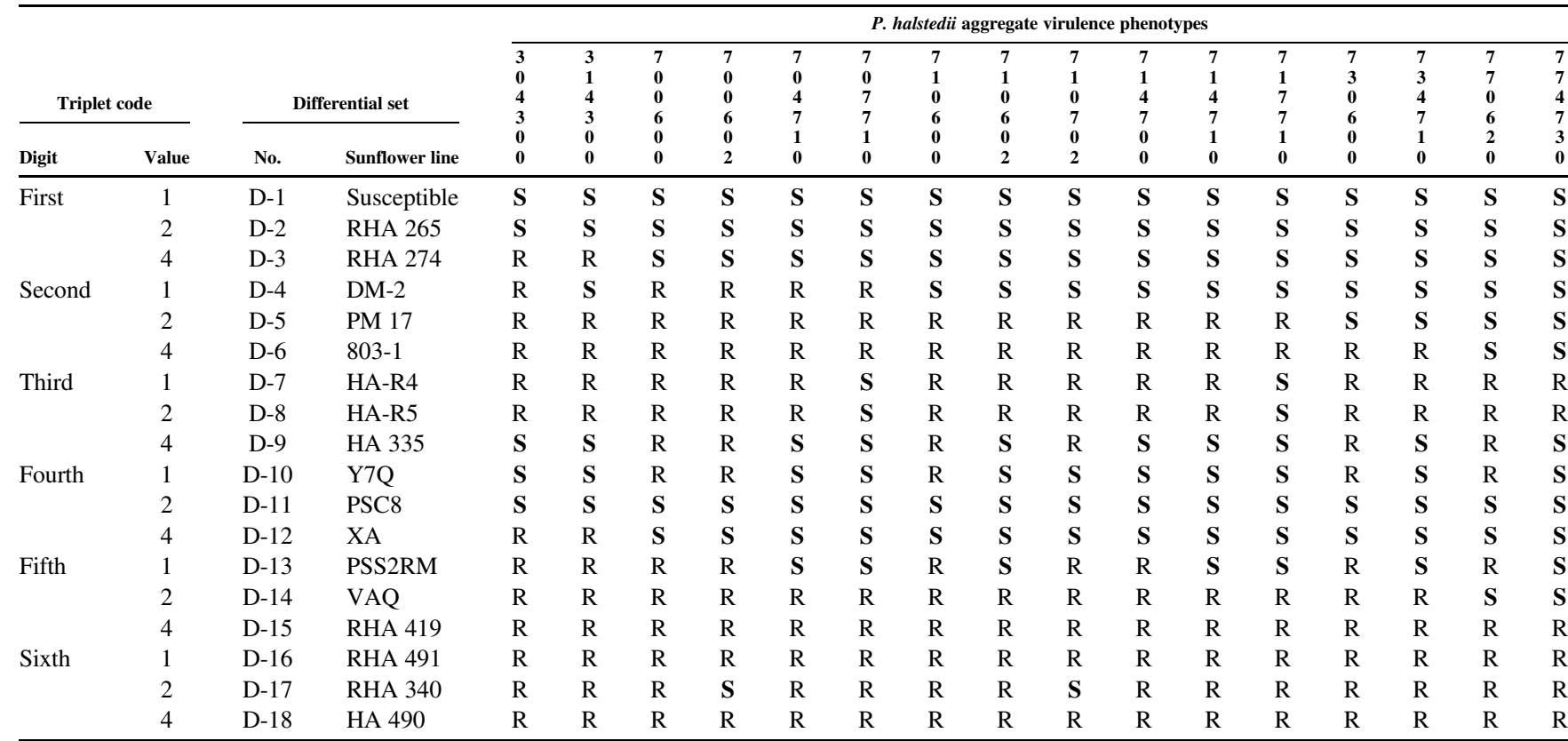

${ }^{a}$ For ease of reading, the virulence phenotypes are listed vertically, so the positions of the digits in the column heads correspond to the positions in the table, and $\mathrm{S}$ (susceptible) is bolded whereas R (resistant) is not. The first differential line in a set of three is given a 1, the second line a 2 , and the third line a 4 ; then the values for all three lines in the set are added and presented as a single number. 
and $\mathrm{Pl}_{15}$ genes (Bazzalo et al. 2016; Trojanová et al. 2017). Although our data suggest that the addition of lines to the differential set is warranted, we acknowledge the added time required for virulence phenotyping when doubling the number of differentials from nine to 18 as well as the difficulty in acquiring differential seed as discussed by Trojanová et al. (2017) and Spring et al. (2018). We further acknowledge that even with the proposed additional lines, the differential set will need to be changed again in the future, because some genes are not represented and novel genes will be identified, and that virulence determination by molecular tools may be a possibility. Given these factors, it is warranted to consider possible changes to the mechanism used to report pathogen virulence in the downy mildew pathosystem in the near future.

The determination of races provides a useful mechanism for quick and uniform interpretation of pathogen virulence, but races contain less useful and precise data than simply reporting virulence phenotypes. In this study, four virulence phenotypes (SI, SII, RI, and RII) are used, but to report races, SI and SII are further categorized as susceptible and RI and RII categorized as resistant (Supplementary Table S1). Thus, differences between similar virulence phenotypes, which may be important for interpretation of results, such as SII (abundant sporulation on cotyledons only) and RII (weak sporulation on cotyledons only), are not apparent in race data. These data can be particularly important when host genotypes are added or replaced, or when subtle differences in technique or rater interpretation can potentially influence the evaluation. As examples from this study, RII was most frequently identified on differential D-5 (PM 17) but was rarely reported on many others (Supplementary Table S1). Second, it is possible that a potentially variable inoculum concentration could have existed and contributed to subtle reaction differences (such as SII and RII), because zoosporangia were only microscopically enumerated in representative inoculum solutions. Lastly, race data will not reflect alterations made in the conventions used to determine virulence phenotype, which have varied over time and geography in this pathosystem (Tourvieille de Labrouhe et al. 2000, 2012; Trojanová et al. 2017).

Races also come with logistical limitations that challenge their utility (Milus 2015). First, limitations occur as novel genes are discovered and deployed over broad geographies. Race systems often dictate that new differentials are added in combinations, such as in triplets as in this pathosystem. However, novel genes are discovered (and deployed) over time, so the virulence data acquired by established differential sets may lack the most important genes. Similarly, hybrids grown in different production regions may contain different resistance genes, rendering data generated on specific differentials in one production region relevant, but data in another irrelevant. Secondly, once a system to classify races is established, pathogen isolates must be evaluated to every differential in the established differential set, regardless of whether the gene confers useful resistance or has been deployed into commercial cultivars. This increases the effort and cost to determine virulence, yet yields information that is of decreasing value. Third, although the use of "race" nomenclature provides a convenient way for pathologists to communicate about pathogen virulence, it creates communication barriers between pathologists and agronomists, breeders, and growers, whose concern may be limited to whether or not one single gene is effective in a specific cultivar grown in a specific region.

The constraints imposed by the use of race systems and race nomenclature also make it difficult to implement changes that make the systems more efficient. For example, differentials used in the common bean (Phaseolus vulgaris) rust (Uromyces appendiculatus) pathosystem were reduced from 19 to 12, and races were named in a numerical system similar to the $P$. halstedii nomenclature but were presented as two groups of sextets (Stavely 1984; Stavely et al. 1983; Steadman et al. 2002). These improvements increased efficiency for determination of virulence and relevance by inclusion of important genes (Steadman et al. 2002). However, it may be difficult to add another sextet of differentials if needed in the future. Additionally, communicating the differences in virulence of historic populations evaluated on the replaced differential set to populations evaluated on the new differential set is difficult. In the soybean cyst nematode (Heterodera glycines) pathosystem, a replacement of the race system with a classification system that directly reports virulence has been adopted (Niblack et al. 2002). Virulence of $H$. glycines on soybeans is evaluated on specific indicator lines and reported as a virulence formula called $\mathrm{Hg}$ type (Niblack et al. 2002). For example, avirulence on indicator lines 1, 3, 4, and 6 and virulence on indicator lines 2,5 , and 7 would be reported as $\mathrm{Hg}$ 2.5.7. This system allows the easy addition of lines with new resistance genes, provides a mechanism to report virulence if only a subset of indicator lines is used, and communicates virulence information in a straightforward manner allowing interpretation of data by a broad audience. A similar system was proposed in the sunflower downy mildew pathosystem in 1990, in which a gene-based nomenclature could be used to compare virulence phenotypes among countries (Gulya et al. 1991, 1998; Sackston et al. 1990; Vear et al. 1997). However, this was not adopted because it was deemed cumbersome and because some of the $P l$ genes are actually clusters of genes that provide resistance to one or more races (Gulya et al. 1998; Vear et al. 1997). Although this study currently supports and recommends the addition of another three triplet sets of differentials to ensure that data acquired in the current race system are relevant, we also recommend considering a restructuring or replacement of the sunflower downy mildew race system in the near future. Possibilities could include a new race system in which antiquated or unused genes are eliminated, elimination of the race system in lieu of direct reporting of virulence or virulence phenotypes from only genes of interest, or potentially future development of a molecular tool for virulence assessment.

Molecular genetic characterization of $P$. halstedii populations has been undertaken using several different DNA sequence features and molecular markers (As-sadi et al. 2011; Delmotte et al. 2008; Gascuel et al. 2016; Rivera et al. 2016; Roeckel-Drevet et al. 2003;

Table 4. Current race nomenclature (three digits) and proposed race nomenclature (six digits) using aggregate virulence phenotypes of Plasmopara halstedii isolates collected in 2014 and 2015 in the North Central Great Plains

\begin{tabular}{|c|c|c|c|c|}
\hline $\begin{array}{l}\text { Race based } \\
\text { on standard } \\
\text { differential } \\
\text { lines }^{\mathrm{a}}\end{array}$ & $\begin{array}{c}\text { Number of } \\
2014 \text { isolates } \\
\text { screened } \\
\text { with all } 18 \\
\text { differential } \\
\text { lines/total } \\
\text { isolates } \\
\text { screened }\end{array}$ & $\begin{array}{c}\text { Six-digit } \\
\text { aggregate } \\
\text { virulence } \\
\text { phenotype }^{\text {b }}\end{array}$ & $\begin{array}{c}\text { Number of } \\
2015 \text { isolates } \\
\text { screened } \\
\text { with all } 18 \\
\text { differential } \\
\text { lines/total } \\
\text { isolates } \\
\text { screened }\end{array}$ & $\begin{array}{c}\text { Six-digit } \\
\text { aggregate } \\
\text { virulence } \\
\text { phenotype }^{b}\end{array}$ \\
\hline 304 & $1 / 1$ & 304300 & - & - \\
\hline 314 & $0 / 3$ & - & $8 / 10$ & 314300 \\
\hline \multirow[t]{2}{*}{700} & $4 / 19$ & 700600 & $0 / 19$ & - \\
\hline & $1 / 19$ & 700602 & $1 / 19$ & 700602 \\
\hline 704 & $1 / 1$ & 704710 & $2 / 4$ & 704710 \\
\hline 707 & $1 / 1$ & 707710 & - & - \\
\hline \multirow[t]{3}{*}{710} & $11 / 33$ & 710600 & $3 / 25$ & 710600 \\
\hline & $1 / 33$ & 710602 & $3 / 25$ & 710602 \\
\hline & - & - & $1 / 25$ & 710702 \\
\hline \multirow[t]{2}{*}{714} & $1 / 37$ & 714700 & - & - \\
\hline & $5 / 37$ & 714710 & $2 / 17$ & 714710 \\
\hline 717 & - & - & $1 / 1$ & 717710 \\
\hline 730 & - & - & $1 / 1$ & 730600 \\
\hline 734 & $1 / 1$ & 734710 & - & - \\
\hline 770 & - & - & $1 / 1$ & 770620 \\
\hline 774 & $1 / 9$ & 774730 & $2 / 2$ & 774730 \\
\hline
\end{tabular}

a Race nomenclature according to Gulya et al. (1998) and Tourvieille de Labrouhe et al. (2000), where the first differential line in a set of three is given a 1 , the second line a 2 , and the third line a 4 ; then the values for all three lines in the set are added and presented as a single number.

${ }^{b}$ Proposed race nomenclature for the six-digit aggregate virulence phenotype includes the addition of six INRA proposed lines (Institut National de la Recherche Agronomique, France, Tourvieille de Labrouhe et al. 2012) as digits four and five and three supplemental lines as digit six. Specifically, these are sunflower lines Y7Q, PSC8, and XA for digit four, sunflower lines PSS2RM, VAQ, and RHA 419 for digit five, and sunflower lines RHA 491, RHA 340, and HA 490 for digit six. 
Spring et al. 2006). These efforts have been accompanied by attempts to correlate the virulence phenotypes observed for $P$. halstedii races with genetic markers. However, no comprehensive molecular diagnostic has yet been developed to successfully differentiate $P$. halstedii races using convenient molecular markers. A recent study focused on French races of $P$. halstedii reported the development of a two-level key composed of 22 single nucleotide polymorphisms (SNPs) interrogated by KASP (KBioscience competitive allele specific PCR) assays that could distinguish most, but not all, of the $14 \mathrm{P}$. halstedii races evaluated (Gascuel et al. 2016). The SNP markers used in this study were developed based on sequence information for predicted RXLR and CRN (crinkler) type effectors, which are expected to exhibit higher levels of diversity due to their predicted involvement in the interaction of the pathogen with its host. Although this study provides an encouraging advance toward a potential molecular diagnostic system for $P$. halstedii race determination, it should be noted that the study considered only isolates collected from France and only a very limited number of isolates per race, with six of the 14 races represented by only a single isolate. Additionally, even though a small number of isolates from a narrow geographical region were evaluated, considerable intrarace variation was observed for specific markers in some races. Consequently, a considerable amount of additional research will be required, including the evaluation of large, global collections of isolates representing all known races, to determine the feasibility of developing a comprehensive molecular diagnostic tool for $P$. halstedii race typing.

The sunflower industry in the United States is fortunate to have at least four resistance genes that are believed to be completely effective, $P l_{A r g}, P l_{15}, P l_{17}$, and $P l_{18}$, as well as three resistance genes, $\mathrm{Pl}_{8}, \mathrm{Pl}_{13}$, and $\mathrm{Pl}_{16}$, for which limited virulence has been observed. However, the number of resistance genes that have been overcome by the pathogen in the North Central Great Plains is alarming, and effort should be made to prolong the effectiveness of genes. This can be done by utilizing an integrated pest management (IPM) strategy, which is designed to manage disease in a sustainable manner and also protect the longevity of management tools (Knodel et al. 2018). For downy mildew management, an IPM approach in the Northern Great Plains states may include the use of highly efficacious fungicide seed treatments (Friskop et al. 2018; Humann et al. 2019). Deploying hybrids that have multiple effective resistance genes is also likely to increase the longevity of resistance genes and provide more durable resistance than single gene deployment. Frequent monitoring of pathogen virulence is a critical step in this process but is only as effective as the tools used to monitor it. This mandates that a continual evolution of differentials that contain relevant resistance genes be incorporated into commercial hybrids and suggests that the most efficient and effective manner to determine and report virulence be adopted.

\section{Acknowledgments}

We thank Drs. Ryan Humann, Bob Harveson, and Febina Mathew for pathogen samples; Presley Mosher, Ian Gilley, and other undergraduate students for their technical support; and the National Sunflower Association for their support of this research and commitment to the professional development of graduate students.

\section{Literature Cited}

As-sadi, F., Carrere, S., Gascuel, Q., Hourlier, T., Rengel, D., Le Paslier, M.-C., Bordat, A., Boniface, M.-C., Brunel, D., Gouzy, J., Godiard, L., and Vincourt, P. 2011. Transcriptomic analysis of the interaction between Helianthus annuиs and its obligate parasite Plasmopara halstedii shows single nucleotide polymorphisms in CRN sequences. BMC Genomics 12: 498.

Bazzalo, E., Huguet, N., and Romano, C. 2016. History and present state of downy mildew in Argentina. Pages. 828-832 in: Proceedings of the 19th International Sunflower Conference, Edirne, Turkey.

Bertero de Romano, A., Romano, C., Bulos, M., Alteri, E., and Sala, C. 2010. A new gene for resistance to downy mildew in sunflower. Pages 142-147 in: Proceedings, International Sunflower Association Symposium: Progress in Breeding Sunflower for Resistance to Disease, Krasnodar, Russia, 21-24 June.

CABI. 2016. Datasheet report for Plasmopara halstedii (downy mildew of sunflower). In: Invasive Species Compendium. CAB International, Wallingford, U.K. https://www.cabi.org/isc.
Carson, M. L. 1981. New race of Plasmopara halstedii virulent on resistant sunflowers in South Dakota. Plant Dis. 65:842-843.

Constantinescu, O., and Thines, M. 2010. Plasmopara halstedii is absent from Australia and New Zealand. Pol. Bot. J. 55:293-298. https://www.cabi.org/ isc/abstract/20113020914

Delmotte, F., Giresse, X., Richard-Cervera, S., M'Baya, J., Vear, F., Tourvieille, J., Walser, P., and Tourvieille de Labrouhe, D. 2008. Single nucleotide polymorphisms reveal multiple introductions into France of Plasmopara halstedii, the plant pathogen causing sunflower downy mildew. Infect. Genet. Evol. 8:534-540

Dußle, C. M., Hahn, V., Knapp, S. J., and Bauer, E. 2004. Pl $l_{\text {Arg }}$ from Helianthus argophyllus is unlinked to other known downy mildew resistance genes in sunflower. Theor. Appl. Genet. 109:1083-1086.

Friskop, A., Markell, S. G., Khan, M., Gudmestad, N., and Secor, G. 2018. 2019 North Dakota Field Crop Plant Disease Management Guide. Publication PP-622. North Dakota State University Cooperative Extension Service, Fargo, ND.

Gascuel, Q., Bordat, A., Sallet, E., Pouilly, N., Carrere, S., Roux, F., Vincourt, P., and Godiard, L. 2016. Effector polymorphisms of the sunflower downy mildew pathogen Plasmopara halstedii and their use to identify pathotypes from field isolates. PLoS One 11:e0148513.

Gascuel, Q., Martinez, Y., Boniface, M.-C., Vear, F., Pichon, M., and Godiard, L. 2015. The sunflower downy mildew pathogen Plasmopara halstedii. Mol. Plant Pathol. 16:109-122

Gilley, M., and Markell, S. 2019. Virulence update for downy mildew of sunflowers. In: Proceedings, 41st Annual Sunflower Research Forum. National Sunflower Association, Mandan, ND.

Gilley, M., Misar, C., Gulya, T., and Markell, S. 2016. Prevalence and virulence of Plasmopara halstedii (downy mildew) in sunflowers. In: Proceedings, 38th Annual Sunflower Research Forum. National Sunflower Association, Mandan, ND.

Gulya, T. 1996. Everything you should know about downy mildew testing but were afraid to ask. Pages 39-48 in: Proceedings, 18th Sunflower Research Workshop, Fargo, ND. 11-12 January. National Sunflower Association, Mandan, ND

Gulya, T., Harveson, R., Mathew, F., Block, C., Thompson, S., Kandel, H. Berglund, D., Sandbakken, J., Kleingartner, L., and Markell, S. 2019. Comprehensive disease survey of U.S. sunflower: Disease trends, research priorities and unanticipated impacts. Plant Dis. 103:601-618

Gulya, T., Kandel, H., McMullen, M., Knodel, J., Berglund, D., Mathew, F. Lamey, H. A., Nowatzki, J., and Markell, S. 2013. Prevalence and incidence of sunflower downy mildew in North Dakota between 2001 and 2011. Plant Health Prog. 14. doi: 10.1094/PHP-2013-0522-01-RS

Gulya, T., Rashid, K. Y., and Masirevic, S. M. 1997. Sunflower diseases. Pages 263-379 in: Sunflower Technology and Production. A. A. Schneiter, ed. American Society of Agronomy, Madison, WI

Gulya, T. J. 1995. Proposal for a revised system of classifying races of sunflower downy mildew. Pages 76-78 in: Proceedings, 17th Sunflower Research Workshop, Fargo, ND. 12-13 January. National Sunflower Association, Mandan, ND.

Gulya, T. J., Markell, S. G., McMullen, M. V., Harveson, R. M., and Osborne, L. E. 2011. Emergence of new virulent races of Plasmopara halstedii inciting downy mildew on sunflower in the United States. Abstracts of Presentations at the 2011 North Central Division Meeting, Omaha, NE. Phytopathology 101:S2.1-S2.10.

Gulya, T. J., Miller, J. F., Virányi, F., and Sackston, W. E. 1991. Proposed internationally standardized methods for race identification of Plasmopara halstedii. Helia 14:11-20.

Gulya, T. J., Misar, C., Markell, S. G., Humann, R., and Harveson, R. M. 2014. 2013 Update on sunflower downy mildew in the U.S.: No new races. Poster presented at 36th Annual Sunflower Research Forum, January 2014, Fargo, ND. National Sunflower Association, Mandan, ND.

Gulya, T. J., Tourvieille de Labrouhe, D., Masirevic, S., Penaud, A., Rashid, K., and Virányi, F. 1998. Proposal for standardized nomenclature and identification of races of Plasmopara halstedii (sunflower downy mildew). Pages 130-136 in: Proceedings, International Sunflower Association Symposium III, Sunflower Downy Mildew, Fargo, ND. Gulya, T. J., and Vear, F. eds.

Hulke, B. S., Ma, G., Qi, L. L., and Gulya, T. J. 2018. Registration of oilseed sunflower germplasms RHA 461, RHA 462, RHA 463, HA 465, HA 466 HA 467, and RHA 468 with diversity in Sclerotinia resistance, yield, and other traits. J. Plant Regist. 12:142-147.

Humann, R. M., Johnson, K. J., Wunsch, M. W., Meyer, S. M., Jordahl, J. G., Bauske, E. C., Halvorson, J. M., Friskop, A. F., O’Bryan, K., Gulya, T. J., and Markell, S. G. 2019. Evaluation of oxathiapiprolin for the management of sunflower downy mildew. Plant Dis. 103:2498-2504.

Imerovski, I., Dimitrijevic, A., Miladinovic, D., Jocic, S., Dedic, B., Cvejic, S., and Surlan-Momirovic, G. 2014. Identification and validation of breeder-friendly DNA markers for $P l_{A r g}$ gene in sunflower. Mol. Breed. 34:779-788.

Iwebor, M., Antonova, T., and Saukova, S. 2018. Occurrence and distribution of races 713, 733 and 734 of sunflower downy mildew pathogen in the Russian Federation. Helia 41:141-151.

Knodel, J. J., Beauzay, P., Friskop, A., and Markell, S. 2018. IPM Basics: Integrated Pest Management in North Dakota Agriculture. Publication 
PP863. North Dakota State University Cooperative Extension Service, Fargo, ND.

Kolte, S. J. 1985. Diseases of Annual Edible Oilseed Crops. Vol. III: Sunflower, Safflower and Nigerseed Diseases. CRC Press, Boca Raton, FL.

Leppik, E. E. 1966. Origin and specialization of Plasmopara halstedii complex on the Compositae. FAO Plant Prot. Bull. 10:126-129.

Liu, Z., Gulya, T. J., Seiler, G. J., Vick, B. A., and Jan, C. C. 2012. Molecular mapping of the $P l_{16}$ downy mildew resistance gene from HA-R4 to facilitate marker-assisted selection in sunflower. Theor. Appl. Genet. 125:121-131.

Liu, Z., Zhang, L., Ma, G. J., Seiler, G. J., Jan, C. C., and Qi, L. L. 2019. Molecular mapping of the downy mildew and rust resistance genes in a sunflower germplasm line TX16R. Mol. Breed. 39:19.

Ma, G. J., Markell, S. G., Song, Q. J., and Qi, L. L. 2017. Genotyping-bysequencing targeting of a novel downy mildew resistance gene $\mathrm{Pl}_{20}$ from wild Helianthus argophyllus for sunflower (Helianthus annuus L.). Theor. Appl. Genet. 130:1519-1529.

Ma, G. J., Seiler, G. J., Markell, S. G., and Qi, L. L. 2018. Registration of three confection sunflower germplasm, HA-DM2, HA-DM3, and HA-DM4, resistant to downy mildew and rust. J. Plant Regist. 13:103-108.

Markell, S. G., Humann, R. M., Gilley, M., and Gulya, T. J. 2016. Downy mildew pathogen: Plasmopara halstedii. Pages 115-117 in: Compendium of Sunflower Diseases and Pests. R. M. Harveson, S. G. Markell, C. C. Block, and T. J. Gulya, eds. APS Press, St. Paul, MN.

Miller, J. F., and Gulya, T. J. 1991. Inheritance of resistance to race 4 of downy mildew derived from interspecific crosses in sunflower. Crop Sci. 31:40-43.

Miller, J. F., Gulya, T. J., and Seiler, G. J. 2002. Registration of five fertility restorer sunflower germplasms. Crop Sci. 42:989-991.

Miller, J. F., Gulya, T. J., and Vick, B. A. 2004. Registration of two maintainer (HA 434 and HA 435) and three restorer (RHA 436 to RHA 438) high oleic oilseed sunflower germplasms. Crop Sci. 44:1034-1035.

Milus, E. A. 2015. Three principles for more informative virulence surveys for wheat rusts. Proceedings of the Borlaug Global Rust Initiative. September 17-20, 2015. Sydney, Australia.

Molinero-Ruiz, M. L., Dominguez, J., and Melero-Vara, J. M. 2002. Races of isolates of Plasmopara halstedii from Spain and studies on their virulence. Plant Dis. 86:736-740.

Molinero-Ruiz, M. L., Melero-Vara, J. M., and Dominguez, J. 2003. Inheritance of resistance to two races of sunflower downy mildew (Plasmopara halstedii) in two Helianthus annuus L. lines. Euphytica 131:47-51.

Money, K., Koehler, B., Misar, C., Grove, M., Underwood, W., and Hulke, B. 2019. Registration of oilseed sunflower germplasms RHA 485, RHA 486, and HA 487, selected for resistance to Phomopsis stalk canker and Sclerotinia, in a highyielding and high-oil background. J. Plant Regist. 13:439-442.

Mulpuri, S., Liu, Z., Feng, J., Gulya, T. J., and Jan, C. C. 2009. Inheritance and molecular mapping of a downy mildew resistance gene, $\mathrm{Pl}_{13}$ in cultivated sunflower (Helianthus annuus L.). Theor. Appl. Genet. 119:795-803.

Niblack, T. L., Arelli, P. R., Noel, G. R., Opperman, C. H., Orf, J. H., Schmitt, D. P., Shannon, J. G., and Tylka, G. L. 2002. A revised classification scheme for genetically diverse populations of Heterodera glycines. J. Nematol. 34:279-288.

Paniego, N., Bazzalo, M. E., Bulos, M., Lia, V., Fusari, C., Alvarez, D., Altieri, E., Ramos, M. L., Galella, M. T., Kaspar, M., and Heinz, R. 2012. Genomics, mapping and marker assisted selection strategies for disease resistance. Pages 44-50 in: Proceedings, 18th International Sunflower Conference, Mar del Plata, Argentina.

Pecrix, Y., Buendia, L., Penouilh-Suzette, C., Maréchaux, M., Legrand, L., Bouchez, O., Rengel, D., Gouzy, J., Cottret, L., Vear, F., and Godiard, L. 2019. Sunflower resistance to multiple downy mildew pathotypes revealed by recognition of conserved effectors of the oomycete Plasmopara halstedii. Plant J. 97:730-748.

Pecrix, Y., Penouilh-Suzette, C., Muños, S., Vear, F., and Godiard, L. 2018. Ten broad spectrum resistances to downy mildew physically mapped on the sunflower genome. Front. Plant Sci. 9:1780.

Qi, L. L., Foley, M. E., Cai, X. W., and Gulya, T. J. 2016. Genetics and mapping of a novel downy mildew resistance gene, $P l_{18}$, introgressed from wild Helianthus argophyllus into cultivated sunflower (Helianthus annuus L.). Theor. Appl. Genet. 129:741-752.

Qi, L. L., Long, Y. M., Jan, C. C., Ma, G. J., and Gulya, T. J. 2015. $P l_{17}$ is a novel gene independent of known downy mildew resistance genes in the cultivated sunflower (Helianthus annuus L.). Theor. Appl. Genet. 128:757-767.

Rahim, M., Jan, C. C., and Gulya, T. J. 2002. Inheritance of resistance to sunflower downy mildew races 1, 2 and 3 in cultivated sunflower. Plant Breed. 121:57-60.

Rashid, K. Y. 2014. Changes in sunflower downy mildew races in Manitoba, 20042013. Poster presented at 36th Annual Sunflower Research Forum, January 2014, Fargo, ND. Unpublished conference poster. National Sunflower Association, Mandan, ND.

Rivera, Y., Salgado-Salazar, C., Gulya, T. J., and Crouch, J. A. 2016. Newly emerged populations of Plasmopara halstedii infecting rudbeckia exhibit unique genotypic profiles and are distinct from sunflower-infecting strains. Phytopathology 106:752-761.
Roath, W. W., Miller, J. F., and Gulya, T. 1986. Registration of sunflower parental lines HA 821 and HA 822. Crop Sci. 26:217.

Roeckel-Drevet, P., Tourvieille, J., Gulya, T. J., Charmet, G., Nicolas, P., and Tourvieille de Labrouhe, D. 2003. Molecular variability of sunflower downy mildew, Plasmopara halstedii, from different continents. Can. J. Microbiol. 49:492-502.

Sackston, W. E., Gulya, T. J., and Miller, J. F. 1990. A proposed international system for designating races of Plasmopara halstedii. Plant Dis. 74 $721-723$

Spring, O. 2019. Spreading and global pathogenic diversity of sunflower downy mildew-Review. Plant Prot. Sci. 55:149-158.

Spring, O., Bachofer, M., Thines, M., Riethmüller, A., Göker, M., and Oberwinkler, F. 2006. Intraspecific relationship of Plasmopara halstedi isolates differing in pathogenicity and geographic origin based on ITS sequence data. Eur. J. Plant Pathol. 114:309-315.

Spring, O., Gomez-Zeledon, J., Hadziabdic, D., Trigiano, R. N., Thines, M., and Lebeda, A. 2018. Biological characteristics and assessment of virulence diversity in pathosystems of economically important biotrophic oomycetes. Crit. Rev. Plant Sci. 37:439-495.

Stavely, J. R. 1984. Pathogenic specialization in Uromyces phaseoli in the United States and rust resistance in beans. Plant Dis. 68:95-99.

Stavely, J. R., Freytad, G. F., Steadman, J. R., and Schwartz, H. F. 1983. The 1983 bean rust workshop. Annu. Rep. Bean Improv. Coop. 26:iv-vi.

Steadman, J. R., Pastor-Corrales, M. A., and Beaver, J. S. 2002. An overview of the 3rd Bean Rust and 2nd Bean Common Bacterial Blight International Workshops, March 4-8, 2002, Pietermaritzburg, South Africa. Annu. Rep. Bean Improv. Coop. 45:120-125.

Talukder, Z. I., Ma, G., Hulke, B. S., Jan, C.-C., and Qi, L. L. 2019. Linkage mapping and genome-wide association studies of the $R f$ gene cluster in sunflower (Helianthus annuus L.) and their distribution in world sunflower collections. Front. Genet. 10:216.

Tourvieille de Labrouhe, D., Brodat, A., Tourvieille, J., Mestries, E., Walser, P., Sakr, N., Ducher, M., Delmotte, F., and Vear, F. 2010. Impact of major gene resistance management for sunflower on fitness of Plasmopara halstedii (downy mildew) populations. Ol. Corps Gras Lipides 17:56-64.

Tourvieille de Labrouhe, D., Gulya, T. J., Masirevic, S., Penaud, A., Rashid, K. Y., and Virányi, F. 2000. New nomenclature of races of Plasmopara halstedii (sunflower downy mildew). Pages 161-166 in: Proceedings, 15th International Sunflower Conference, Toulouse, France, 12-15 June.

Tourvieille de Labrouhe, D., Serre, F., Walser, P., Roche, S., and Vear, F. 2008 Quantitative resistance to downy mildew (Plasmopara halstedii) in sunflower (Helianthus annuus). Euphytica 164:433-444.

Tourvieille de Labrouhe, D., Walser, P., Jolivot, D., Roche, S., Serre, F., Leguillon, M., Delmotte, F., Bordat, A., Godiard, L., Vincourt, P., and Vear, F. 2012. Proposal for improvement of sunflower downy mildew race nomenclature. Pages 322-327 in: Proceedings, 18th International Sunflower Conference, Mar del Plato, Argentina.

Trojanová, Z., Sedlářová, M., Gulya, T. J., and Lebeda, A. 2017. Methodology of virulence screening and race characterization of Plasmopara halstedii, and resistance evaluation in sunflower-A review. Plant Pathol. 66:171-185.

U.S. Department of Agriculture, Foreign Agricultural Service (USDA-FAS). 2019 World Agricultural Production: Sunflower seed Area, Yield, and Production. Circular Series WAP 7-19. Page 26.

U.S. Department of Agriculture, National Agricultural Statistics Service (USDANASS). 2019. Crop Production 2018 Summary: Sunflower Area Planted and Harvested, Yield, and Production by Type - States and United States: 20162018. ISSN:1057-7823. Pages 50-51.

Vear, F., Gentzbittel, L., Philippon, J., Mouzeyar, S., Mestries, E., Roeckel-Drevet, P., Tourvieille de Labrouhe, D., and Nicolas, P. 1997. The genetics of resistance to five races of downy mildew (Plasmopara halstedii) in sunflower (Helianthus annuus L.). Theor. Appl. Genet. 95:584-589.

Vear, F., Serieys, H., Petit, A., Serre, F., Boudon, J. P., Roche, S., Walser, P., and Tourvielle de Labrouhe, D. 2008. Origins of major genes for downy mildew resistance in sunflower. Pages 8-12 in: Proceedings, 17th International Sunflower Conference, Córdoba, Spain.

Vincourt, P., As-sadi, F., Bordat, A., Langlade, N. B., Gouzy, J., Pouilly, N., Lippi, Y., Serre, F., Godiard, L., Tourvielle de Labrouhe, D., and Vear, F. 2012. Consensus mapping of major resistance genes and independent QTL for quantitative resistance to sunflower downy mildew. Theor. Appl. Genet. 125: 909-920.

Virányi, F., Gulya, T. J., and Tourvieille de Labrouhe, D. 2015. Recent changes in the pathogenic variability of Plasmopara halstedii (sunflower downy mildew) populations from different continents. Helia 38:149-162.

Zhang, Z. W., Ma, G. J., Zhao, J., Markell, S. G., and Qi, L. L. 2017. Discovery and introgression of the wild sunflower-derived novel downy mildew resistance gene $\mathrm{Pl}_{19}$ in confection sunflower (Helianthus annuus L.). Theor. Appl. Genet. 130:29-39.

Zimmer, D. E., and Kinman, M. L. 1972. Downy mildew resistance in cultivated sunflower and its inheritance. Crop Sci. 12:749-751. 